\title{
Metalloproteinases and tumor necrosis factor-alpha activities in synovial fluids of horses: correlation with articular cartilage alterations
}

\author{
Maggy Jouglin ${ }^{\text {a* }}$, Céline RoberT ${ }^{\mathrm{a}}$, Jean-Paul VAlette ${ }^{\mathrm{a}}$, \\ Françoise GAVARD $^{\mathrm{b}}$, Françoise QuINTIN-COLONNA ${ }^{\mathrm{b}}$, \\ Jean-Marie DENOIX ${ }^{\mathrm{a}}$
a UMR INRA-DGER Biomécanique du Cheval, École Nationale Vétérinaire d'Alfort, 7 avenue du Général de Gaulle, 94704 Maisons-Alfort Cedex, France
${ }^{\mathrm{b}}$ Institut d'Immunologie Animale et Comparée, École Nationale Vétérinaire d'Alfort, 7 avenue du Général de Gaulle, 94704 Maisons-Alfort Cedex, France

(Received 12 August 1999; accepted 29 May 2000)

\begin{abstract}
Early detection of osteoarthritis in horses represents a challenge for equine practitioners. Several biological markers have been implicated in the pathological processes involved in articular cartilage destruction. To further document cartilage matrix proteases production, synovial fluid was collected from 14 horses (90 joints) before they were subjected to euthanasia. Growth macroscopic examination of the joints gave information on cartilage alterations. Samples were analyzed for matrix metalloproteinase (MMPs) activities by gelatin zymography and tumor necrosis factor alpha (TNF- $\alpha$ ) cytotoxicity using L929 cells. Significant increase of MMP-9 monomer and dimer were found in synovial fluids of joints with severe cartilage alterations. On the contrary, the activity of TNF- $\alpha$ was not correlated to the degree of joint damage. The levels of MMP-9 monomer and dimer in the synovial fluid could reflect cartilage alteration in arthritis in the horse.
\end{abstract}

horse / osteoarthritis / synovial fluid / metalloproteinase / tumor necrosis factor alpha

Résumé - Activité des métalloprotéinases et du tumor necrosis factor-alpha dans le liquide synovial de chevaux : corrélation avec les altérations du cartilage articulaire. Le dépistage précoce des arthropathies reste un défi pour le vétérinaire équin. Certains marqueurs biologiques présents dans le liquide synovial pourraient être des indicateurs précoces de l'ostéoarthrose. C'est pourquoi, le liquide synovial de 90 articulations de 14 chevaux devant être euthanasiés a été recueilli. La dissection des articulations prélevées a ensuite permis de visualiser les surfaces articulaires. Pour chaque échantillon, l'activité des métalloprotéinases (MMPs) a été évaluée par zymographie et la cytotoxicité du tumor necrosis factor alpha (TNF- $\alpha$ ) a été mesurée sur culture cellulaire. La corrélation des

* Correspondence and reprints

Tel.: (33) 1439670 85; fax: (33) 1439631 62; e-mail: jouglin@ vet-alfort.fr 
résultats de l'examen macroscopique et des dosages biochimiques montre une augmentation significative de l'intensité des MMP-9 monomère et dimère dans le liquide synovial des articulations présentant des lésions cartilagineuses graves. En revanche, l'activité du TNF- $\alpha$ n'apparaît pas corrélée à la gravité de l'atteinte articulaire. Les taux de MMP-9 monomère et dimère dans le liquide synovial de chevaux semblent donc être de bons témoins de l'altération du cartilage articulaire.

cheval / ostéoarthrose / liquide synovial / métalloprotéinase / tumor necrosis factor alpha

\section{INTRODUCTION}

Joint disease has a major impact on equine athletic performance. Osteoarthritis (OA) is characterised by biochemical deterioration of the articular cartilage, accompanied by changes in bone and soft tissues of the joint [16]. OA results in varying grades of lameness. Its diagnosis is usually based on clinical signs and abnormal imaging findings. Early stages of cartilage degradation often remain difficult to investigate. Identification of specific biological markers of OA could be a useful complementary tool.

Synovial cells are a rich source of proteolytic enzymes active against both collagens and proteoglycans in equine joints [17]. Matrix metalloproteinases (MMPs) are an important group of zinc enzymes and are classified in three main groups called stromelysins, collagenases and gelatinases [19]. They play a role in the homeostasis of connective tissue. In joint disease, they can also be responsible for degradation of the extracellular matrix components of cartilage such as collagens and proteoglycans [6]. Cartilage matrix proteases production and cartilage matrix degradation by chondrocytes are induced, among other mediators, by tumor necrosis factor alpha (TNF- $\alpha$ ) $[1,18]$ while tissue inhibitors of metalloproteinases (TIMPs) control connective tissue breakdown by blocking the action of the activated enzymes and by preventing activation of the proenzymes $[4,10]$.

The present study investigated several biological markers that could be representative of the extent of cartilage degradation. The purpose was to analyse how MMPs and
TNF- $\alpha$ activities in the synovial fluid are correlated to the macroscopic appearance of the articular cartilage.

\section{MATERIALS AND METHODS}

\subsection{Horses and synovial fluid samples}

Ninety synovial fluid samples were obtained by arthrocentesis under sterile conditions in no additive vacutainer tubes, from the joints of 14 horses, 3-15 years old (mean: 5 years) at stall rest, before they were subjected to euthanasia for conditions unrelated to joint disease. Samples came from 26 tibiotarsal joints, 26 radiocarpal joints, 27 fetlocks and 11 coffin joints. Synovial fluids were centrifuged at $2500 \mathrm{~g}$ during $10 \mathrm{~min}$. at $4{ }^{\circ} \mathrm{C}$, aliquoted and stored at $-80{ }^{\circ} \mathrm{C}$.

\subsection{Macroscopic examination}

Post mortem, joints were skinned and opened, and articular surfaces were examined. The joints were listed according to the predominant type of joint disorder: osteochondrosis (OCD) with peri-articular osteochondral fragmentation, degenerative joint disease (DJD) with peri-articular bony proliferation and enlarged synovial fossa (ESF). The latter refers to joints with a cartilage defect, where the subchondral bone was visible, but with no sign of degenerative process (DJD) and no cartilage or bony fragment free in the joint (OCD). Such findings are often referred to as anatomical variation, 
but, their size was abnormally large and frequently associated to synovial distension.

Then, joints were scored according to the number of the disorder (OCD, DJD and ESF) and the severity of the cartilage lesions according to 5 grades:

$0=$ normal joint;

1 = minor changes: one disorder without cartilage alteration;

$2=$ mild changes: one disorder with superficial cartilage fibrillation;

3 = moderate changes: one or two disorders with cartilage fibrillation and softening;

4 = numerous or severe changes: one or several disorders with deep or full thickness cartilage lesions.

\subsection{Gelatin zymography}

The biological activities of enzymes were measured in each sample using gelatin zymography.

\subsubsection{Gelatinase activity}

Synovial fluid samples were diluted in unreduced buffer Tris/ $\mathrm{HCl}$ and incubated at $37{ }^{\circ} \mathrm{C}$ for $60 \mathrm{~min}$. The method described by Bradford [2] was used to estimate the total protein concentration in synovial fluid samples. Aliquots of $25 \mu \mathrm{g}$ of total proteins were deposited in a well on the gel before the electrophoresis was conducted. Gelatinase enzyme activity was assayed by a sodium dodecyl sulphate-polyacrylamide gel electrophoresis (SDS-PAGE) gelatin zymography as described [8] with modifications. Gelatin was co-polymerised with $10 \%$ polyacrylamide gels at a final concentration of $2.5 \mathrm{mg} \cdot \mathrm{mL}^{-1}$. The gels were washed in Triton X-100 $2.5 \%$ buffer, and incubated in reactivation buffer $50 \mathrm{mM}$ Tris- $\mathrm{HCl} \mathrm{pH} \mathrm{7.4}$ (50 $\mathrm{mM} \mathrm{CaCl}_{2}, 10 \mathrm{mM} \mathrm{NaCl}, 0.05 \%$ Brij 35). They were stained with $5 \mathrm{mg} \cdot \mathrm{L}^{-1}$ Coomassie brilliant blue R 250. The gelatinolytic activities were inhibited by $20 \mathrm{mM}$ EDTA (MMPs inhibitor). This assay con- firmed that the enzymes were specific metalloendopeptidases.

\subsubsection{Quantification of collagenolytic activity in synovial fluids}

Zones of clearing on the blue-stained gel showed degradation of gelatin. The apparent molecular weights of MMPs were obtained with reference to standard molecular weight markers (Amersham, code RPN 756, $14.3-220 \mathrm{kDa}$ ). For a given band of lysis, the extent of substrate clearing was estimated by densitometry. Gel images were captured using an assisted computer video camera (Densylab, Photo-capt Systems). For each band of clearing, the relative intensity was determined using the band surface, proportional to the amount of matrix metalloproteinases present.

\subsection{TNF assay}

The cytotoxicity assay for TNF- $\alpha$ was performed as described [15] using cells of the tumorigenic fibroblast-like mouse cell line L929. Thus, $1.5 \times 10^{4}$ cells were seeded in $100 \mu \mathrm{L}$ of medium in each well of 96well microtitration plates. After incubation of the samples, cells were stained with $50 \mu \mathrm{L}$ of $0.033 \%$ neutral red. Plates were incubated for $1 \mathrm{~h}$ at $37^{\circ} \mathrm{C}$, centrifuged and washed in phosphate buffer saline. Cells were destroyed in buffer (ethanol/sodium phosphate, monobasic $0.1 \mathrm{M}$; v/v). Cell survival was quantified with an automated microplate reader equipped with a $540 \mathrm{~nm}$ filter. On each plate, 8 wells containing cells incubated in medium alone served as the negative control (100\% survival).

The TNF- $\alpha$ value (in Units $\cdot \mathrm{mL}^{-1}$ ) was calculated, after deducing the optical density negative control, as the reciprocal of the dilution responsible for a $50 \%$ reduction in cell survival. The TNF- $\alpha$ titer, that was estimated to cause exactly $50 \%$ cytotoxicity, contained 1 Unit of TNF- $\alpha$ activity $\cdot \mathrm{mL}^{-1}$. 


\subsection{Statistical analysis}

Data were treated by the multivariate discriminant analysis procedure (DA). This method takes into account all the information given by the quantitative variables (total proteins, MMP-9 monomer, MMP-9 dimer and TNF- $\alpha$ ). The groups of cartilage alteration were compared with the maximum within-group variance by determining a set of new uncorrelated variables (1st, 2nd and 3rd components) defined by a linear combination of the variables. This analysis also provided correlation coefficients between all the variables, means (SD) and a 1-way analysis of variance.

\section{RESULTS}

\subsection{Macroscopic examination}

Joint samplings were irregularly distributed according to the type and the grade of the lesions (Fig. 1). OCD was mainly observed in the tarsus with more grade 1 than grade 2 or 3 lesions. DJD was essentially found in the fetlock joint with more grade 1 and 2 lesions than grade 3 and 4 lesions. Most of the ESFs were graded 2.

Cartilage alterations varied from one joint to the others. Most of the coffin joints and carpus were normal. The fetlocks were equally distributed in each group of cartilage alterations. Most of the tarsus presented lesions graded 1, 2 and 3.

\subsection{Gelatin zymography}

Total protein count was not statistically different between groups with a mean of $10.6 \mathrm{~g} \cdot \mathrm{L}^{-1}$ (SD 6.4) (Tab. I). Nevertheless, its quantification allowed to deposit the same quantity of proteins in each electrophoresis well.

The standard of reference gave the molecular weights of the different enzyme bands (Figs. 2 and 3). The 90 joint samples examined revealed a large protein band at $66 \mathrm{kDa}$ which was due to the activity of the MMP-2 latent form. Sometimes a thin band

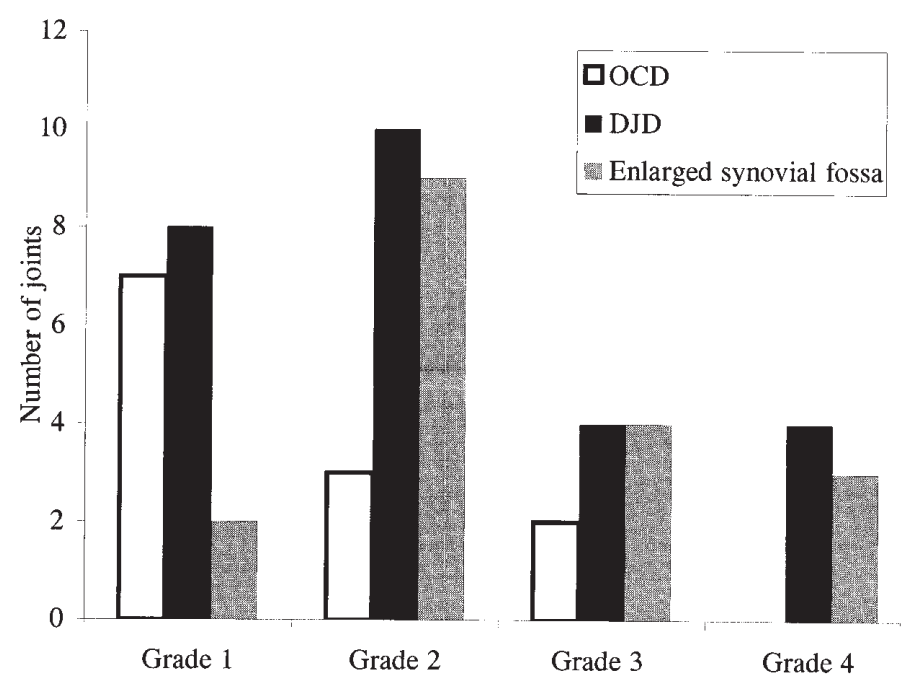

Figure 1. Distribution of the lesions according to clinical entity and severity. OCD: Osteochondrosis, DJD: Degenerative Joint Disease, ESF: Enlarged Synovial Fossa. 
Table I. Analysis of variance of total proteins, MMPs and TNF- $\alpha$ in the different groups of severity.

\begin{tabular}{|c|c|c|c|c|c|c|c|}
\hline & \multicolumn{5}{|c|}{ Severity } & \multirow{2}{*}{$\begin{array}{c}F \\
(4 / 85 \mathrm{ddl})\end{array}$} & \multirow{2}{*}{$\begin{array}{l}\text { Statistical } \\
\text { significance }\end{array}$} \\
\hline & 0 & 1 & 2 & 3 & 4 & & \\
\hline $\begin{array}{l}\text { Total proteins } \\
\left(\mathrm{g} \cdot \mathrm{L}^{-1}\right)\end{array}$ & $\begin{array}{l}12.46 \\
(7.66)\end{array}$ & $\begin{array}{c}9.34 \\
(4.72)\end{array}$ & $\begin{array}{c}9.66 \\
(4.89)\end{array}$ & $\begin{array}{c}7.81 \\
(4.96)\end{array}$ & $\begin{array}{l}13.56 \\
(3.62)\end{array}$ & 2 & ns \\
\hline $\begin{array}{l}\text { MMP-2 } \\
\text { (Relative intensity*) }\end{array}$ & $\begin{array}{c}3.83 \\
(0.96)\end{array}$ & $\begin{array}{c}4.50 \\
(0.64)\end{array}$ & $\begin{array}{c}3.98 \\
(0.97)\end{array}$ & $\begin{array}{c}4.46 \\
(0.69)\end{array}$ & $\begin{array}{c}4.00 \\
(0.01)\end{array}$ & 2.46 & $\mathrm{~ns}$ \\
\hline $\begin{array}{l}\text { MMP-9 monomer } \\
\text { (Relative intensity*) }\end{array}$ & $\begin{array}{r}1.28^{\mathrm{a}} \\
(0.60)\end{array}$ & $\begin{array}{r}1.09^{\mathrm{a}} \\
(0.43)\end{array}$ & $\begin{array}{r}1.50^{\mathrm{a}} \\
(0.76)\end{array}$ & $\begin{array}{r}1.68^{\mathrm{a}} \\
(0.79)\end{array}$ & $\begin{array}{l}2.75^{\mathrm{b}} \\
(1.09)\end{array}$ & 5.54 & $p<0.001$ \\
\hline $\begin{array}{l}\text { MMP-9 dimer } \\
\text { (Relative intensity*) }\end{array}$ & $\begin{array}{c}0.11^{\mathrm{a}} \\
(0.36)\end{array}$ & $\begin{array}{l}0.15^{\mathrm{a}} \\
(0.33)\end{array}$ & $\begin{array}{l}0.15^{\mathrm{a}} \\
(0.36)\end{array}$ & $\begin{array}{l}0.14^{\mathrm{a}} \\
(0.35)\end{array}$ & $\begin{array}{l}1.12^{\mathrm{b}} \\
(0.54)\end{array}$ & 6.76 & $p<0.0001$ \\
\hline $\begin{array}{l}\text { TNF- } \alpha \\
\left(\text { Units of TNF activity } \cdot \mathrm{mL}^{-1} \text { ) }\right.\end{array}$ & $\begin{array}{c}0.61 \\
(0.37)\end{array}$ & $\begin{array}{c}0.67 \\
(0.34)\end{array}$ & $\begin{array}{c}0.58 \\
(0.30)\end{array}$ & $\begin{array}{c}0.44 \\
(0.29)\end{array}$ & $\begin{array}{c}0.80 \\
(0.49)\end{array}$ & 1.21 & ns \\
\hline
\end{tabular}

Mean values were given with their standard deviations.

Means with the same letter were not statistically different.

* The relative intensity was determined using the band surface, proportional to the amount of matrix metalloproteinases present.

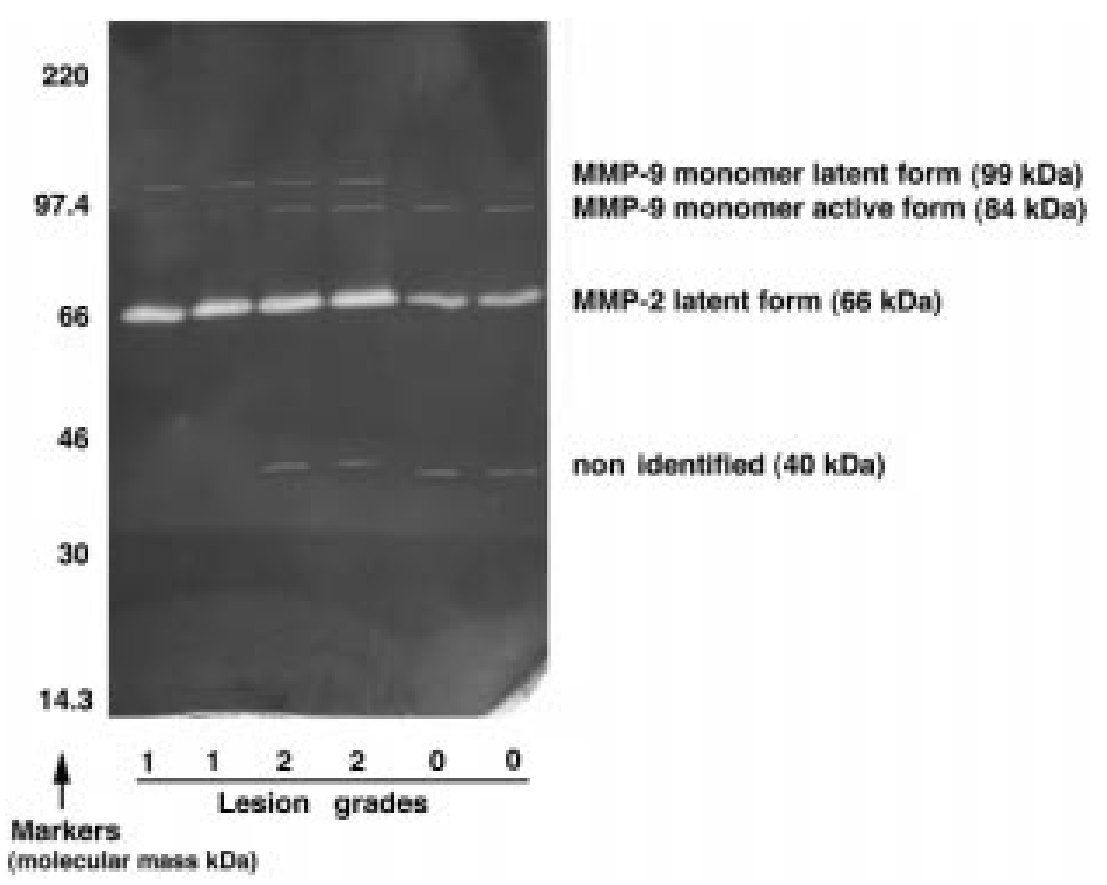

Figure 2. SDS-PAGE of gelatinolytic activity in synovial fluids coming from joints presenting moderate lesions (grade 0 to 2). MMPs molecular weights were determined with reference to marker migration (left column). 


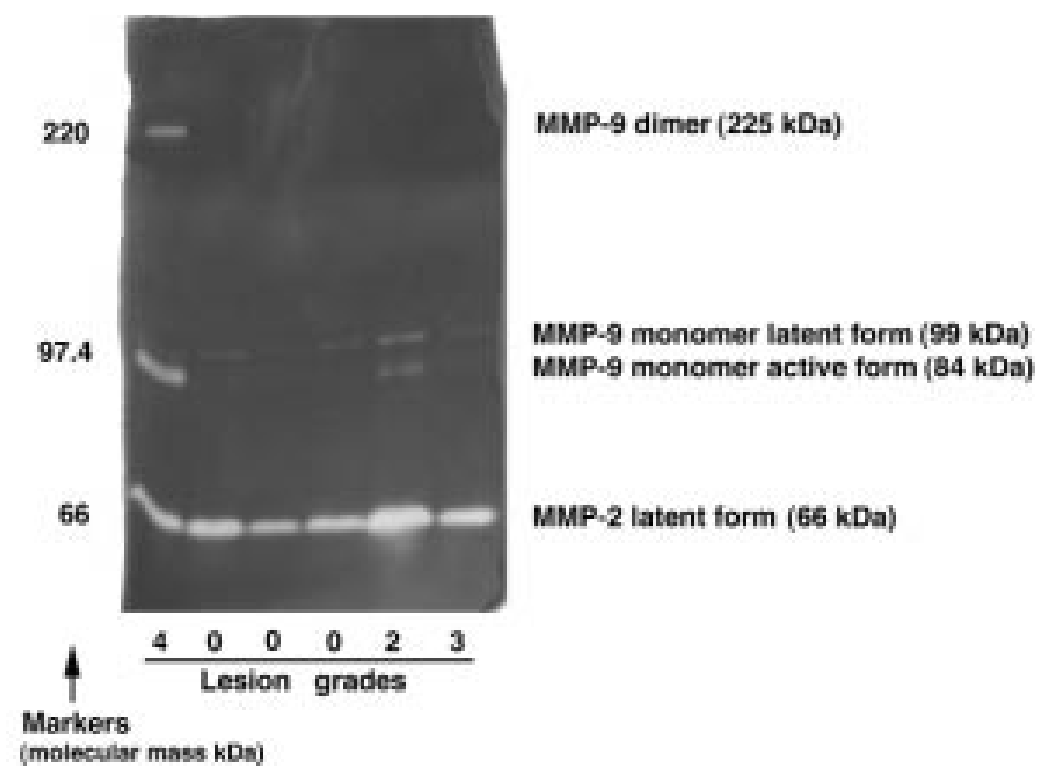

Figure 3. SDS-PAGE of gelatinolytic activity in synovial fluids from joints presenting slight to severe lesions (grade 0 to 4 ).

at $59 \mathrm{kDa}$ was seen, due to the activity of the MMP-2 active form. In the diseased joints, activity could be seen at $99 \mathrm{kDa}$ and sometimes at $84 \mathrm{kDa}$ and $225 \mathrm{kDa}$. The $99 \mathrm{kDa}$ enzyme activity was due to the MMP-9 monomer latent form, the $84 \mathrm{kDa}$ band was due to the MMP-9 monomer active form and the $225 \mathrm{kDa}$ band was due to the dimer of MMP-9.

Enzyme activity did not differ with the type of joint (coffin joint, fetlock, carpus or tarsus) and there was no significant difference between the OCD, DJD and ESF group. There was a linear relationship $(r=0.54, p<0.001)$ between the activities of the MMP-9 monomer and the MMP-9 dimer. The activities of MMP-9 monomer tended to increase with the gravity of the lesions and showed a statistically significant increase in group 4 (Tab. I). Group 4 also demonstrated a significant increase in the MMP-9 dimer activity compared to the other synovial fluid groups (Tab. I).
Others enzymes were responsible for thin gelatinolytic bands around $40 \mathrm{kDa}$. Their presence or absence in synovial fluid samples was not correlated to articular lesions.

\subsection{TNF assay}

The TNF- $\alpha$ activity detected in the synovial fluid samples did not differ significantly for the groups (Tab. I) with a mean value of $30 \%$ cytotoxicity (corresponding to 0.6 Unit of TNF- $\alpha$ activity $\cdot \mathrm{mL}^{-1}$ ). Nevertheless, it tended to increase in joints with grade 4 lesions.

\subsection{Relationship between TNF- $\alpha$ activity and concentrations of total protein}

This study showed a significant correlation between TNF- $\alpha$ activity and the concentrations of total protein $(r=0.31$, $p<0.05)$. 


\subsection{Discriminant analysis}

Figure 4 shows the location of the centres of gravity of the groups of severity on the 3 axes of the discriminant analysis procedure. The first component included the MMP-9 monomer and dimer parameters, while TNF- $\alpha$ and the total proteins represented the second and third components respectively. The closer the parameters are to the periphery, the more correlated with severity of cartilage alteration they are. Parameters or groups situated close to the center of the graph are not clearly explained by the first, second and third components which represented 48.2, 26.2 and $22.6 \%$ of the total variance, respectively. Analysis of variance revealed that the activity of the MMP-9 monomer and dimer was significantly correlated with the severity of cartilage alterations. The group of gravity 4, on axis 1 , was associated with MMP-9 and this axis could measure cartilage alterations. MMP-9 (monomer and dimer) were not on the same axis as TNF- $\alpha$. Thus, MMP-9 are not correlated to TNF- $\alpha$, but these parameters could give complementary information on the grade of severity. The DA procedure also calculated the probability of misclassification of a horse in another group according to all the parameter values. When considering all grades independently, it was found that only $36.7 \%$ of the values were correctly assigned to the group they were initially assigned to. When considering grades 0 to 2 on the one hand and grades 3 and 4 on the other hand, $66.7 \%$ of the values were well classified.

\section{DISCUSSION}

Early diagnosis of osteoarthritis is a major problem in veterinary medicine. Activation of MMPs is considered to be an important factor in the control of extracellular proteolysis [7] and proinflammatory cytokines (IL-1 and TNF- $\alpha$ ) stimulate numerous cell types including chondrocytes, to secrete

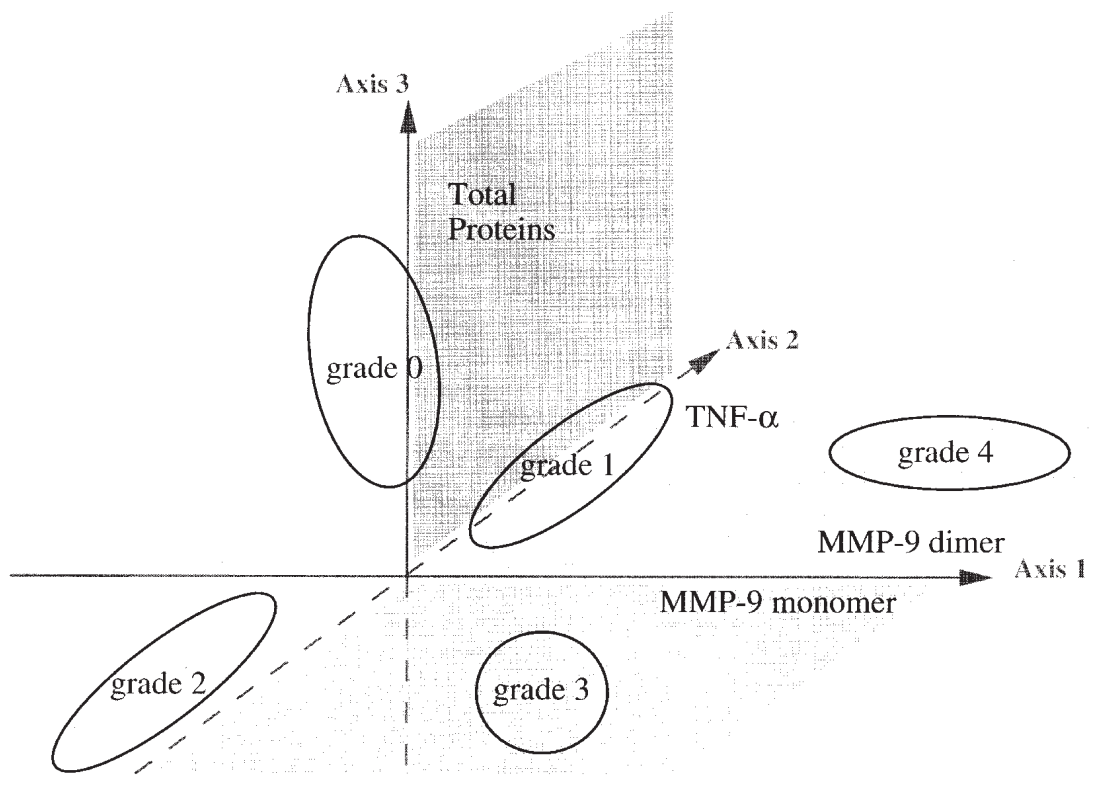

Figure 4. Location of the centres of gravity of the 5 grades of severity on the 3 axes of the discriminant analysis procedure. 
both collagenase and stromelysin [6]. The present study was performed to assess the occurrence of MMPs and TNF- $\alpha$ in different grades of joint disease. The joints were scored according to a macroscopic exam which allows to visualise the complete articular surface.

Horses were at stall rest in the weeks before samples were obtained in order to minimize the effects of inflammation induced by activity. In humans, MMP-9 levels are reported to differ between inflammatory and mechanical joint fluids [11].

MMPs were assayed directly by zymography. This assay is highly specific, because it is based on a direct enzyme-substrate interaction, and gives information on the molecular weights of the enzymes (latent or active form). The gelatinases found in this study were comparable to those reported by Clegg et al. [9] from aseptic and septic joint samples.

In the present study, the latent form of MMP-2 was detected in all synovial fluids. Clegg et al. [9] also demonstrated that MMP-2 was present in both normal and abnormal equine synovial fluids: the levels of MMP-2 were significantly higher in both aseptic and septic equine joint disease in comparison with synovial fluids from horses with no diagnosed joint disease. Johnson et al. [14] observed an increase in the activity of $66 \mathrm{kDa}$ proteinases in the laminitic tissues and suggest that the $72 \mathrm{kDa}$ are converted to $66 \mathrm{kDa}$ by proteolytic cleavage. These authors have hypothesised that other proteinases were capable of activating $72 \mathrm{kDa}$ gelatinase. The pattern of multiple bands after activation indicates the presence of latent and active forms of MMPs in the laminar tissue. In humans, levels of activated MMP-2 were similar in joints with inflammatory disorders and with mechanical disorders [11]. The mechanism underlying the MMP-2 overactivity remains unclear but could involve defective regulation by TIMP-2 [10], which is the main inhibitor of MMP-2, or a defective expression of
TIMP-2. TIMP-2 would have a role in assisting the activation of MMP-2 by facilitating the binding of the enzyme to the cell surface and therefore its activation by the membrane type-MMP (MT-MMP) [5, 12].

The present study demonstrated that high levels of MMP-9 were present in the synovial fluid from joints with severe cartilage alterations in all joint diseases (OCD, DJD or ESF). The occurrence of the active form of the MMP-9 monomer was associated to the presence of a degenerative process. These results are in agreement with the data from Clegg et al. [9] who found a rise in MMP-9 activities in a broad range of aseptic joint diseases. In osteoarthritic joints, Brama et al. [3] also found the MMP-9 activity was nearly twice as high as in normal joints, but, in OCD joints, MMPs activity was not significantly different from normal control joints. In humans with rheumatoid arthritis, the concentrations of MMP-2 and 9 in synovial fluids do not seem to be influenced by the amount of residual cartilage [13]. In ESF joints, the increase of MMP-9 levels cannot be explained by cartilage alterations only. ESF probably results from a synovial inflammatory reaction, and it is reported that infiltrating inflammatory cells produce MMP-9 monomer and dimer in equine joints $[8,9]$.

This study also showed a significant increase of MMP-9 dimer in the joints with grade 4 lesions. This result is explained by in vitro studies: stimulation of diseased equine articular cells and tissues causes not only an increase in MMP-9 production, but also an increase in the amount of activated enzymes released [7]. When MMP-9 monomer is present in excess, the dimerisation occurs relative to TIMPs in the ratio 1:1 (monomer MMP-9/TIMP complex) [8].

Studies of cytokines in joint tissues suggest that TNF- $\alpha[1,18]$ modulates and stimulates the synthesis of MMPs by both chondrocytes and synovial cells and is an important mediator in joint disease. In the 
present study, the TNF- $\alpha$ activity was not correlated to the severity of cartilage alterations, although it increased in group 4. This may be explained by the absence of inflammation (stall rest horses) or the presence of inhibitors or other antagonist cytokines in the joints. Billinghurst et al. [1] indeed, found that the difference in TNF- $\alpha$ levels from synovial fluids from the control group and synovial fluids from chronic cases of arthropathy was not statistically significant, but showed that a significant increase in intra-articular TNF- $\alpha$ occurred during acute inflammation in the same diseased joints when compared to the normal joints. These authors concluded that determination of the TNF- $\alpha$ levels in equine joints could be of limited diagnostic value in assessment of arthritis.

As a conclusion, synovial fluid MMPs may be used as markers of changes that occur in the joints with osteoarthritis. MMP9 monomer, in particular, seems strongly correlated to the severity of cartilage alterations. Arthrocenthesis in order to get a synovial fluid sample and gelatin zymography could provide useful information to the equine practitioner in the presence of a horse with articular distension. Further studies are still needed to investigate other biological parameters.

\section{REFERENCES}

[1] Billinghurst R.C., Fretz P.B., Gordon J.R., Induction of intra-articular tumor necrosis factor during acute inflammatory responses in equine arthritis, Equine Vet. J. 27 (1995) 208-216.

[2] Bradford M., A rapid and sensitive method for the quantitation of microgram quantities of protein utilising the principle of protein-dye binding, Anal. Biochem. 72 (1976) 248-254.

[3] Brama P.A., Tekoppele J.M., Beeckman B., van Weeren P.R., Barneveld A., Matrix metalloproteinase activity in equine synovial fluid: influence of age, osteoarthritis, and osteochondrosis, Ann. Rheum. Dis. 57 (1998) 697-699.

[4] Birkedal-Hansen H., Moore W.G.I., Bodden M.K., Windsor L.J., Birkedal-Hansen B., Decarlo A., Engler J.A., Matrix metalloproteinases: a review, Crit. Rev. Oral Biol. Med. 4 (1993) 197250 .
[5] Cao J., Sato H., Takino T., Seiki M., The C-terminal region of membrane type matrix metalloproteinase is a functional transmembrane domain required for pro-gelatinase A activation, J. Biol. Chem. 270 (1995) 801-805.

[6] Cawston T.E., Proteinases and inhibitors, Br. Med. Bull. 51 (1995) 385-401

[7] Clegg P.D., Carter S.D., Matrix metalloproteinase2 and -9 are activated in joint diseases, Equine Vet. J. 31 (1999) 324-330.

[8] Clegg P.D., Burke R.M., Coughlan A.R., Riggs C.M., Carter S.D., Characterisation of equine matrix metalloproteinase 2 and 9 , and identification of the cellular sources of these enzymes in joints, Equine Vet. J. 29 (1997) 335-342.

[9] Clegg P.D., Coughlan A.R., Riggs C.M., Carter S.D., Matrix metalloproteinases 2 and 9 in equine synovial fluids, Equine Vet. J. 29 (1997) 343348.

[10] Clegg P.D., Coughlan A.R., Carter S.D., Equine TIMP-1 and TIMP-2: Identification, activity and cellular sources, Equine Vet. J. 30 (1998) 416423.

[11] Gaudin P., Razakaboay M., Surla A., Berthier S., Fauconnier J., Morel F., Phelip X., A study of metalloproteinases in fifty joint fluid specimens, Rev. Rhum. Engl. Ed. 64 (1997) 375-381.

[12] Itoh Y., Binner S., Nagase H., Steps involved in activation of the complex of pro-matrix metalloproteinase 2 (progelatinase A) and TIMP2 by 4-APMA, Biochem. J. 308 (1995) 645-651.

[13] Ishiguro N., Ito T., Miyazaki K., Iwata H., Matrix metalloproteinases, tissue inhibitors of metalloproteinases, and glycosaminoglycans in synovial fluid from patients with rheumatoid arthritis, J. Rheumatol. 26 (1999) 34-40.

[14] Johnson P.J., Tyagi S.C., Katwa L.C., Ganjam V.K., Moore L.A., Kreeger J.M., Messer N.T., Activation of extracellular matrix metalloproteinases in equine laminitis, Vet. Rec. 142 (1998) 392-396.

[15] Mackay R.J., Merritt A.M., Zertuche J.M., Whittington M., Skelley L.A., Tumor necrosis factor activity in the circulation of horses given endotoxin, Am. J. Vet. Res. 52 (1991) 533-538.

[16] McIlwraith C.W., General pathobiology of the joint and response to injury, in Joint Disease in the Horse, Saunders Ed. (1996) 40-70.

[17] Spiers S., May S.A., Bennett D., Edwards G.B., Cellular sources of proteolytic enzymes in equine joints, Equine Vet. J. 26 (1994) 43-47.

[18] Todhunter P.G., Kincaid S.A., Todhunter R.J., Kammermann J.R., Johnstone B., Baird A.N., Hanson R.R., Wright J.M., Lin H.C., Purohit R.C., Immunohistochemical analysis of an equine model of synovitis-induced arthritis, Am. J. Vet. Res. 57 (1996) 1080-1093.

[19] Woessner J.F., Matrix metalloproteinases and their inhibitors in connective tissue remodeling, Fed. Amer. Soc. Exp. Biol. J. 5 (1991) 21452154 . 